\title{
Collateral Benefits and Front Pay: A Rule of No Offset Encourages Agency Recoupment
}

\author{
Eric Pearsont
}

If an employee is wrongfully discharged for discriminatory reasons he may sue his employer to receive compensation in the form of lost wages and the right to be reinstated to the same position. If reinstatement is not possible, the monetary award can continue into the future, allowing the employee a reasonable amount of time to find comparable employment. ${ }^{2}$

The employee's discharge may also trigger (or increase) a collateral benefit distributed by a third party, such as unemployment compensation or a pension benefit. If the employee is able to collect both his lost wages (for example, $\$ 1,000$ per month in salary) because he cannot be reinstated, and the collateral benefit (for example, $\$ 200$ per month in unemployment benefits) he will receive $\$ 1,200$ per month$\$ 200$ more than he would earn if still employed. To avoid this windfall the court may reduce, or offset, the damages that the employer must pay by the amount of the benefit. In our example, with a $\$ 200$ offset, the employee will receive the amount he would have earned if still employed $-\$ 1,000$ per month. However, because the employer will only pay $\$ 800$ per month, it is not forced to internalize the full cost of its actions. In effect, the provider of the benefit subsidizes the harm. ${ }^{3}$ Whether the employee or the employer is credited with the benefit, one side is given a windfall it arguably does not deserve. ${ }^{4}$

There are three potential rules that can be applied in cases involving collateral benefits and front pay awards. First, there may be a

$\dagger$ B.S. 1999, University of Arizona; J.D. Candidate 2003, The University of Chicago.

1 Damages awarded for lost wages between termination and the judgment are known as "back pay." See Dan B. Dobbs, 2 Law of Remedies: Damages-Equity-Restitution § 6.10(4) at 207 (West 2d ed 1993) (describing back pay as the "remedy for past effects of discharge or refusal to hire" measured by "the amount the employee would have earned had the defendant not wrongfully deprived the employee of the job or promotion").

2 Damages awarded for lost wages occurring after the judgment (due to the inability to reinstate the employee or to find a comparable job) are known as "front pay." See id at 205 (describing front pay as "an award for future lost pay ... given in lieu of reinstatement").

3 See Gaworski v ITT Commercial Finance Corp, 17 F3d 1104, 1113 (8th Cir 1994) ("By virtue of state aid ...the employer winds up paying less to the employee than it would have had it not illegally terminated him.").

4 This problem has been described as "minor in dollars but important in principle." Hunter $v$ Allis-Chalmers Corp, Engine Division, 797 F2d 1417, 1428 (7th Cir 1986) (discussing what to do with unemployment benefits in an award of back pay under Title VII). 
rule that, as a matter of law, a front pay award must be reduced by the amount of the collateral benefit ("offset"). Second, there may be a rule that, as a matter of law, the award cannot be reduced ("no offset"), so that an employee receives both the front pay award and the collateral benefit. ${ }^{6}$ Finally, trial courts may be allowed to exercise their discretion in deciding whether to offset the collateral benefits ("discretionary offset"). ${ }^{7}$ Courts are currently split between the rule of no offset and the rule of discretionary offset.

This Comment argues that the best rule of offset is the one that most easily allows an agency to avoid paying out any excess collateral benefit, thereby removing it from the dispute so that the excess does not have to be apportioned between the parties. Removing the excess benefit eliminates the potential problem of awarding a windfall to either side. 'Several courts have noted that such agency "recoupment" is the ideal solution in the context of back pay. ${ }^{10}$ With regard to front pay,

5 No court advocates this possibility. See Gaworski, 17 F3d at 1113 ("[N]o circuit that has considered the matter has determined that unemployment benefits should, as a general rule, be deducted from backpay awards in discrimination cases.").

6 See, for example, Hamlin $v$ Charter Township of Flint, 165 F3d 426, 433-36 (6th Cir 1999) (noting that "the decision of whether to offset collateral pension benefits from a discrimination award is a policy determination that should not be left to the individual discretion of each district court" and holding that collateral benefits should not be offset).

7 See, for example, Lussier v Runyon, 50 F3d 1103, 1107 (1st Cir 1995) (holding that "insofar as front pay is concerned, the effect to be given to collateral benefits-whatever their source-is within the equitable discretion of the district court").

8 Compare Hamlin, 165 F3d at 433 (holding that pension benefits may not be deducted from front pay award under the Americans with Disabilities Act ("ADA")), and Doyne v Union Electric Co, 953 F2d 447, 451 (8th Cir 1992) (holding that pension benefits may not be deducted from front or back pay awards under the Age Discrimination in Employment Act ("ADEA")), with Lussier, 50 F3d at 1107 (holding that district courts have discretion to deduct collateral benefits from front pay awards), and Salveson v Douglas County, 245 Wis 2d 497, 630 NW2d 182, 196-97 (2001) (holding that trial courts have discretion in deciding whether to offset disability benefits from front pay awards under Title VII). There is also no clear rule on how awards of back pay should be handled. See Lussier, 50 F3d at 1108-09 (stating that by its "rough count," courts of appeal have divided four-to-three in favor of granting trial courts discretion to deduct collateral benefits from back pay awards). This Comment focuses on awards of front pay, and because of procedural differences the analysis may not be applicable to certain aspects of back pay.

9 The employee will be placed in the same monetary position as if he were not discriminated against-receiving only front pay equal to his lost wages-and the employer will be forced to pay out that full cost, without the assistance of a subsidy from the agency providing the collateral benefit. Therefore, the employer will be forced to completely internalize the cost of its discrimination. This cost is the full amount of the lost wages resulting from the discrimination because any contribution from a collateral source simply depletes the agency's resources.

10 See, for example, Hunter, 797 F2d at 1429 (stating that the "logical implication" of collateral benefits is not that the employer should get a deduction, but that the employee should have to repay the benefit); Craig v Y \& Y Snacks, Inc, 721 F2d 77, 85 (3d Cir 1983) (concluding that "the recoupment of unemployment benefits by the state is the better way of dealing with any possible unfairness" in a back pay award under Title VII); Kauffman v Sidereal Corp, 695 F2d 343, 347 (9th Cir 1982) ("[I]f Congress did not intend for an employee to receive unemployment benefits in addition to back pay the logical solution is a recoupment of the unemployment benefits by the state employment agency."). 
this means that the third party ("agency") who provides the benefit to the employee will stop paying it out and "recoup" any amount previously overpaid once it learns of the front pay award.

Several states have enacted mechanisms to recoup certain benefits after awards of back pay. ${ }^{12}$ Agencies have also joined suits to recoup benefits previously paid out. ${ }^{13}$ However, no judicial decision or commentary has examined which rule of offset would best enable such recoupment in the area of front pay. ${ }^{14}$

This Comment argues that for front pay awards, a rule of no offset will best enable agencies to recoup the benefits paid out to employees. Part I examines the remedies available to victims of employment discrimination and the relevant federal statutes. Part II examines the case law regarding collateral benefits and front pay and argues that the cases do not persuasively show whether the law mandates a rule of no offset or discretionary offset. Part III demonstrates the functional problems with the application of a rule of discretionary offset. Part IV proposes that in the world of front pay, a rule of no offset provides the best regime for agencies to recoup the benefits they pay out. Part IV.A argues that this clear rule allows the agency to predict exactly what the court will do, enabling it to create a recoupment system. Part IV.B argues that a rule of no offset will have efficiency benefits in lowering administrative costs while ensuring that the most informed party - the agency-will make the decisions about the benefits.

\section{RULES AND REMEDIES FOR EMPLOYMENT DISCRIMINATION}

This Part focuses on the current law governing employment discrimination and the remedies available to the victims of such dis-

11 This Comment uses the term "recoupment" in reference to agencies taking back the benefits they pay out because several cases use that term regarding back pay. In the area of front pay it is not as textually applicable because benefits related to front pay have, by definition, not yet been paid out (except for lump sum payments). So rather than actually recouping the payment the agency simply does not pay it out. However, for ease of terminology this Comment will refer to all actions where the agency keeps the excess as recoupment.

12 See, for example, Ala Code $\$ 25-4-78(6)$ (Lexis 1975) (mandating that in back pay cases unemployment benefits should be deducted from the award and then paid from the employer to the agency); Conn Gen Stat Ann § 46a-86(b) (West 1995) (mandating that unemployment benefits shall be deducted from back pay and shall be paid by the employer to the proper agency). There are several states that have similar statutes for unemployment compensation and one state with a mechanism for pension benefits. See, for example, Nev Rev Stat $\$ 286.435$ (1997) (stating that public employers shall deduct any back pay and forward it to the retirement system).

13 See Jirus v City of Berwyn, 712 F Supp 672,674 (N D Ill 1989) ("[The] court need not confer [ ] a windfall because the missing claimant, the pension fund, has intervened to recoup the benefits paid. The pension fund is rightfully entitled to those funds.").

14 One court has suggested that for back pay a rule of offset may be best. See Dillon $v$ Coles, 746 F2d 998, 1007 (3d Cir 1984). See also note 118. 
crimination. Part I.A describes the collateral source rule and the reasoning behind its development. Part I.B explains the remedies available to employees who are discriminated against with a focus on front pay. Part I.C analyzes the federal employment discrimination statutes and examines how they relate to the rules of front pay and collateral benefits. It also argues that the relationship among the statutes allows for a common background rule applicable to all employment discrimination statutes.

\section{A. The Collateral Source Rule}

The collateral source rule is a common law rule used by courts in determining remedies. Under this rule, benefits received by a plaintiff, from a source collateral to the defendant, may not be used to reduce the defendant's liability. ${ }^{15}$ Two rationales for the rule are that the plaintiff may have "paid" for the benefitt and a preference that windfalls go to victims rather than wrongdoers." Judicial application of the collateral source rule in employment discrimination cases has varied among the courts. ${ }^{18}$

\section{B. Employment Discrimination Remedies}

The general remedy granted to employees for employment discrimination is an award of lost wages for the time between termination and adjudication (back pay), as well as reinstatement with the employer. ${ }^{19}$ Front pay is a monetary remedy available when circumstances dictate that it is not possible for the employee to be reinstated. ${ }^{20}$ Commentators have argued that courts should expand their

15 See Restatement (Second) of Torts, $\$$ 920A ("Payments made to or benefits conferred on the injured party from other sources are not credited against the tortfeasor's liability."). See also Hamlin v Charter Township of Flint, 165 F3d 426, 434 (6th Cir 1999) ("Applying the collateral source rule in the employment discrimination context prevents the discriminatory employer from avoiding liability and experiencing a windfall, and also promotes the deterrence functions of discrimination statutes.").

16 See Dobbs, 2 Law of Remedies $\$ 8.6(3)$ at 495 (cited in note 1) (presenting the argument that if "the plaintiff paid for the benefit he is now receiving . . . the defendant ought not benefit from the plaintiff's investment").

17 See id at $497-98$

18 See note 8 (collecting cases).

19 See Elizabeth Papacek, Comment, Sexual Harassment and the Struggle for Equal Treatment Under Title VII: Front Pay As an Appropriate Remedy, 24 Wm Mitchell L Rev 743, 772-75 (1998) (noting that back pay is a presumptive element of damages under Title VII and the $\mathrm{ADEA}$, and that there is a strong preference for reinstatement in prospective relief); Dobbs, 2 Law of Remedies $\$ 6.10$ (3) at 204 (cited in note 1) (stating that the original remedial approach of employment discrimination statutes treated discrimination as a social and economic tort remedied by reinstatement and back pay).

20 See Pollard v EI du Pont de Nemours \& Co, 532 US 843, 846 (2001) (defining front pay as "money awarded for lost compensation during the period between judgment and reinstatement or in lieu of reinstatement"); Dobbs, 2 Law of Remedies $\S 6.10(4)$ at 213 (cited in note 1) 
use of front pay as a remedy because of the inherent problems involved with a court ordering an employee to return to work. ${ }^{21}$ In fact, it has been suggested that front pay is actually more efficient than reinstatement - in terms of social costs-due to the lowered productivity of the returning employee. ${ }^{z}$ As the remedy of front pay becomes more prevalent, courts will undoubtedly decide more cases involving collateral benefits and front pay.

\section{Employment Discrimination Statutes}

There are several federal laws protecting employees from discrimination in the workplace. Most relevant to the discussion of front pay and collateral benefits are: Title VII, ${ }^{24}$ which protects individuals from employment discrimination based on race, color, religion, sex, and national origin; The Americans with Disabilities Act ("ADA"),

(stating that if reinstatement is not suitable then front pay, "the money claim for future losses," is granted). There are several reasons why reinstatement may not be possible, such as a destroyed working relationship or the fact that similar employment opportunities are no longer available. See, for example, Avitia v Metropolitan Club of Chicago, Inc, 49 F3d 1219, 1231 (7th Cir 1995) (stating that courts should prefer front pay to reinstatement in circumstances where the court would be forced to "exercise continuing supervision" for many years); McKnight v General Motors Corp, 908 F2d 104, 115 (7th Cir 1990) (stating that there should be no reinstatement when it would result in "undue friction and controversy"). But see EEOC v Century Broadcasting Corp, $957 \mathrm{~F} 2 \mathrm{~d} 1446,1462$ (7th $\mathrm{Cir} 1992$ ) (stating that the hostility common to litigation should not be sufficient to deny reinstatement).

21 See, for example, Susan K. Grebeldinger, The Role of Workplace Hostility in Determining Prospective Remedies for Employment Discrimination: A Call for Greater Judicial Discretion in Awarding Front Pay, 1996 U Ill L Rev 319,342-52 (discussing the merits of front pay in lieu of reinstatement).

22 See Avitia, 49 F3d at 1232 (hypothesizing that reinstatement may cost an employer more than it benefits the employee because of the negative effects on productivity). Judge Richard Posner suggests that the employer could buy out the employee with a payment between the cost of reinstatement to the employer and the value of the job to the employee, and notes that an award of front pay avoids this "tricky transaction." Id.

23 Since front pay awards are currently a second choice for courts, much of the case law and commentary on collateral benefits and discrimination compensation relates to back pay. See, for example, Thomas W. Lee, Comment, Deducting Unemployment Compensation and Ending Employment Discrimination: Continuing Conflict, 43 Emory L J 325, 326-27 (1994) (arguing for a rule of no offset of unemployment compensation from back pay awards under Title VII based on equity, congressional intent, and public policy considerations). Courts often apply the rules and analysis of front pay and back pay interchangeably, so it is useful to look to cases involving both remedies in order to fully understand judicial reasoning. However, there are important distinctions between the two awards. In order to avoid confusion, this Comment will refer to both front and back pay cases with clear reference to the particular situation. However, the final proposed solution applies only to front pay because of procedural differences in the distribution of front and back pay. See note 118 and accompanying text.

24 Title VII of the Civil Rights Act of 1964, Pub L No 88-352, 78 Stat 253 (1964), codified as amended at 42 USC $\$ 2000$ e et seq (1994).

25 Americans with Disabilities Act of 1990, Pub L No 101-336, 104 Stat 328 (1990), codified as amended at 42 USC $\$ 12101$ et seq (1994). The Supreme Court has recently held ADA actions by individuals against States to be unconstitutional based on the Eleventh Amendment. See Board of Trustees of the University of Alabama v Garrett, 531 US 356 (2001). Employees looking 
which covers discrimination against individuals with disabilities; and The Age Discrimination in Employment Act ("ADEA"), which generally prohibits employers from discriminating against individuals on the basis of age.

1. Wide statutory scheme.

The Supreme Court has described the collection of employment discrimination statutes as a "wide[] statutory scheme to protect employees in the workplace nationwide." ${ }^{27}$ Courts have often applied the case law of Title VII and the ADEA interchangeably. ${ }^{23}$ In fact, the administrative agency charged with enforcing Title VII and the ADEA applies the same policy statement on remedies and relief for cases under either statute. ${ }^{29}$ The idea that the individual statutes work together in a larger scheme implies that a single background rule applicable to all of the employment discrimination statutes would not be contradictory to judicial interpretation or legislative intent.

\section{Textual analysis.}

The employment discrimination statutes do not provide a definitive answer as to what the courts should do with the excess created by front pay and collateral benefits. The remedy sections of the statutes are silent about the subject of collateral benefits. Most of the statues do not mention back pay, ${ }^{30}$ and none address front pay.

to make claims of disability discrimination against state employers may still have a method of redress under state laws or by having the federal government bring the action. See id at $374 \mathrm{n} 9$. See also William P. Perkins and Michelle L. Toll, Garrett Nixes ADA Damages Suits Versus State, NY L J 1 (Apr 6, 2001) (noting other available remedies such as state laws and the Rehabilitation Act).

26 Age Discrimination in Employment Act of 1967, Pub L No 90-202 § 4f, 81 Stat 602, codified at 29 USC $\$ \$ 621-34$ (1994). Similar to its interpretation of the ADA, the Supreme Court has held the ADEA unconstitutional, under the Eleventh Amendment, when applied against states by individuals. See Kimel v Florida Board of Regents, 528 US 62 (2000). Employees with age discrimination complaints against state employers will still likely be able to bring their claims by doing so under state laws. See id at 91-92.

27 McKennon $v$ Nashville Banner Publishing Co, 513 US 352, 357 (1995) (discussing the ADEA and citing to Title VII, the ADA, and the NLRA).

28 See, for example, Dominguez $v$ Tom James Co, 113 F3d 1188, 1191 (11th Cir 1997) ("Given the analogous nature and purpose of Title VII and the ADEA, our holding in [a Title VII case] applies to ADEA cases as well as Title VII cases."); McKnight v General Motors Corp, 973 F2d 1366, 1369 n 1 (7th Cir 1992) (stating that it would look to both Title VII and ADEA cases in evaluating awards under Title VII). See also Grebeldinger, 1996 U Ill L Rev at 325 (cited in note 21) (stating that courts often apply the case law interchangeably).

29 See Grebeldinger, 1996 U III L Rev at 325 (cited in note 21) (citing EEOC Policy Statement on Remedies and Relief for Individual Cases of Unlawful Discrimination, 29 CFR $\S 1613$, appendix A (1995)).

30 The exception is Title VII, although it is without reference to collateral benefits. See notes 32-37 and accompanying text.

31 The fact that front pay is not specifically mentioned as a remedy should not be taken as 
a) Title VII and the ADA. Title VII, and the ADA, which tracks its remedies, ${ }^{2}$ does provide some textual discussion of the available remedies. Section $706(\mathrm{~g})$ of Title VII authorizes courts to "enjoin the [employer] from engaging in such unlawful employment practice, and order such affirmative action as may be appropriate, which may include, but is not limited to, reinstatement or hiring of employees, with or without back pay." ${ }^{33}$ In 1972, Congress expanded the remedy section, including "any other equitable relief as the court deems appropriate." ${ }^{34}$ However, the only discussion of what to do as to regarding the adjustment of an award is that "[i]nterim earnings or amounts earnable with reasonable diligence by the person or persons discriminated against shall operate to reduce the back pay otherwise allowable." Neither the term "earnings" nor the term "interim earnings" is defined to include collateral benefits.

Aside from this brief discussion of remedies, the text of Title VII provides little guidance in addressing the issue of collateral benefits and front pay. Furthermore, the legislative history of Title VII does not reveal any specific congressional intent regarding collateral benefits. ${ }^{37}$

an indication that it cannot be awarded. The Supreme Court expressly rejected the argument that remedies not specifically mentioned in the employment discrimination statutes are not available. See Franks v Bowman Transportation Co, 424 US 747, 764 n 21 (1976) ("It is true that backpay is the only remedy specifically mentioned in $\$ 706(\mathrm{~g})$. But to draw from this fact ... any implicit statement by Congress that [an alternate remedy] is a prohibited, or at least less available, form of remedy is not warranted."). Many courts have recognized front pay as an available remedy under other discrimination statutes. See Pollard $v$ EI du Pont de Nemours \& Co, 532 US 843, 846 (2001) (implying that front pay is an available remedy under Title VII); Hamlin $v$ Charter Township of Flint, 165 F3d 426, 435-36 (6th Cir 1999) (approving a front pay award under the ADA); Doyne v Union Electric Co, 953 F2d 447 (8th Cir 1992) (approving a front pay award under the ADEA); Cooper v Asplundh Tree Expert Co, 836 F2d 1544, 1553 (10th Cir 1988) (holding that front pay is an available remedy under the ADEA and noting that all other circuits deciding the issue have agreed).

32 See 42 USC $\$ 12117$ (a) (stating that "[ $t$ ] he powers, remedies, and procedures set forth in sections $2000 \mathrm{e}-4,2000 \mathrm{e}-5,2000 \mathrm{e}-6,2000 \mathrm{e}-8$, and $2000 \mathrm{e}-9$ of this title shall be the powers, remedies, and procedures" of the $\mathrm{ADA}$ ).

3342 USC \$2000e-5(g)(1).

34 Id.

35 Id. For one possible interpretation of this statutory language, see Lee, Comment, 43 Emory L J at 343-44 (cited in note 23) (making an expressio unius argument that since interim earnings and amounts earnable with diligence are listed as things to be offset, collateral benefits must not be offset).

36 Earnings have been defined as "[r]evenue gained from labor or services, from the investment of capital, or from assets." Black's Law Dictionary 526 (West 7th ed 1999). Interim earnings refers to the wages that the employee received or should have received from an alternate employer, so that truly collateral benefits are not included. See National Labor Relations Board v Gullett Gin Co, 340 US 361, 363 (1951) ("[B]enefits received by employees under a state unemployment compensation act [are] plainly not earnings which ... [can] be deducted."), citing Marshall Field \& Co v Labor Board, 318 US 253 (1943). See also Dobbs, 2 Law of Remedies § 6.10(4) at 221-22 (cited in note 1) (comparing this to the common law rule of mitigation of damages).

37 See Kauffman v Sidereal Corp, 695 F2d 343, 346 (9th Cir 1982) ("The legislative history 
b) The $A D E A$. The ADEA gives courts jurisdiction "to grant such legal or equitable relief as may be appropriate to effectuate the purposes [of the Act], including without limitation judgments compelling employment, reinstatement or promotion." "The ADEA does not contain any references to collateral benefits or how courts should handle them.

While the text of the statutes are the authoritative source for determining the proper remedies, the employment discrimination statutes do not provide sufficient guidance to determine how to handle collateral benefits and front pay. Therefore, courts deciding the issue should look to enact the rule that best achieves Congress's express and implied goals in remedying discrimination.

\section{Goals of the discrimination statutes.}

The Supreme Court has distilled two primary purposes from Title VII: 1) to eradicate discrimination and 2) to make the victims of employment discrimination whole. These twin goals demonstrate the tension that arises when excess benefits are created by the combination of front pay and collateral benefits. To achieve the first goal effectively a court must make the employer internalize the full cost of its actions. In doing so, however, the court would make the victim more than whole. Granting an offset to avoid this overcompensation, however, creates a system in which the full costs of discrimination are not borne by the employer, thus limiting the deterrence effect of the statute. Courts have interpreted the purpose of the ADEA similarly to the twin goals of Title VII, creating the same dilemma."

To achieve the "twin goals" of this "wide statutory scheme" courts should attempt to make the employee whole while forcing discriminating employers to bear the full cost of their actions. The current case law, however, has failed to establish a consistent rule to achieve these goals.

behind [Title VII] is not enlightening in ascertaining whether Congress intended that unemployment benefits be deducted."). But see Part II.B.1, discussing legislative history that shows that Congress intended Title VII to provide the most complete relief possible.

3829 USC \$ 626(b).

39 See Hansard v Pepsi-Cola Metropolitan Bottling Co, 865 F2d 1461, 1469 (5th Cir 1989) (stating that with regard to the ADEA, "Congress did not specify what remedies are available to aggrieved plaintiffs. Rather, Congress granted courts broad authority to fashion relief.").

40 See Albemarle Paper Co v Moody, 422 US 405, 417-18 (1975). See also Lussier $v$ Runyon, 50 F3d 1103, 1111 (1st Cir 1995) (referring to the "twin goals" of Title VII and citing Albemarle).

41 See, for example, Gibson v Mohawk Rubber Co, 695 F2d 1093, 1097 (8th Cir 1982) (noting that ADEA remedies aim "to eliminate the unlawful practices and to restore aggrieved persons to the position where they would have been if the illegal discrimination had not occurred"). 


\section{CASE LAW: COLLATERAL BENEFITS IN EMPLOYMENT DISCRIMINATION SUITS}

Courts applying the collateral source rule to the employment discrimination statutes can adopt one of three potential approaches. A court could rule that as a matter of law, the employee's front pay award must be reduced by the amount of the collateral benefit, thus adopting an "offset" rule. However, no court has advocated this position. Second, a court could rule that as a matter of law the award cannot be offset by any collateral benefit, thus adopting a "no offset" rule. The third option would be to grant trial courts the discretion to decide whether or not to deduct the benefit from the award, a "discretionary offset" rule. Courts have split over the second and third possibilities for both front pay and back pay awards. ${ }^{42}$

This Part first looks to the Supreme Court's only discussion of collateral benefits and employment discrimination. It then examines lower court decisions that have created conflicting offset rules.

\section{A. National Labor Relations Board v Gullett Gin Co}

The only Supreme Court case to consider collateral benefits and employment discrimination focused solely on back pay, and has actually done more to fuel the current controversy than it has to settle it. In Gullett, the Court affirmed the National Labor Relations Board's ("NLRB") consistent refusal to deduct unemployment compensation from back pay awards under the National Labor Relations Act ("NLRA")."

Because the holding of Gullett is vague, lower courts have interpreted the case in different ways in an attempt to justify whichever rule of offset they wish to apply to collateral benefits. ${ }^{\text {t5 }}$ Those courts advocating a discretionary offset rule reason that the Court affirmed the NLRB's use of discretion, and thus implied that the decision to deduct benefits is discretionary. ${ }^{45}$ On the other hand, those courts applying a no offset rule cite Gullett as evidence that the Court endorsed the nondeductibility of collateral benefits. ${ }^{47}$ This ambiguous precedent

42 See note 8 .

43340 US 361 (1951).

44 See id at 365-66 (stating that the Board has disallowed deductions for many years and may do so to further the policies of the Act). This case is applicable to actions under other employment discrimination statutes because Title VII is modeled on the NLRA. See Craig $v Y \&$ Y Snacks Inc, 721 F2d 77,83 (3d Cir 1983).

45 See Dobbs, 2 Law of Remedies $\$ 6.10(4)$ at 223-24 (cited in note 1) (noting that there is no definitive interpretation of the Court's holding in Gullett).

46 See, for example, EEOC v Sandia Corp, 639 F2d 600, 624 (10th Cir 1980) (stating that the holding in Gullett is that "the Board did not abuse its discretion").

47 See, for example, Brown y A.J. Gerrard Manufacturing Co, 715 F2d 1549, 1551 (11th Cir 1983) (arguing that the Court's acceptance of the Board's consistent denial of deductions meant 
has resulted in the creation of conflicting rules regarding front pay and collateral benefits.

\section{B. The Discretionary Offset Rule}

In Lussier $v$ Runyon, ${ }^{48}$ the First Circuit articulated the most complete argument to date for allowing discretionary offset of front pay awards. In reviewing the trial court's decision, the First Circuit held that it was within the trial court's discretion to offset the front pay award. ${ }^{\text {so }}$ The Lussier court reasoned that since front pay is "generally equitable in nature," courts should have discretion in determining all aspects of front pay. This court argued that if the decision to award or withhold front pay is within the discretion of the trial court, the ability to take collateral benefits into account should also be discretionary, based on the premise that a greater power necessarily includes the lesser, unless expressly denied."

This "brute force of logic" may sound coherent, but without any reasoning it carries little weight. In fact, the rationale for granting discretion in awarding front pay actually works against granting discretion to offset it. There are four reasons why the Lussier court's rationale-and the rationale for discretionary offset in general-must fail: 1) the legislative history on the purpose of Title VII, 2) the lack of precedent, 3) the implications of the "uncertain nature" of front pay, and 4) the nature of equity.

\section{Legislative history.}

Courts arguing for discretion in discrimination remedies often rely on the Supreme Court's citation to the legislative history on the

that this practice became settled back pay law under the NLRA).

4850 F3d 1103 (1st Cir 1995).

49 Lussier was wrongfully terminated because he suffered from post-traumatic stress disorder, a violation of the Rehabilitation Act, which provides the remedies authorized by Title VII. See id at 1105 . Lussier received an increase in his Veterans Administration benefits due to this discharge. Because Lussier could not return to his old position, the trial court awarded him front pay. In order to prevent a windfall to Lussier the trial court reduced the award by the resulting increase in his Veterans Administration benefits over the period of front pay. See id. See also Graefenhain v Pabst Brewing Co, 870 F2d 1198, 1210 (7th Cir 1989) ("Whether to deduct pension benefits from a front pay award is a matter committed to the discretion of the trial court."); Salveson v Douglas County, 245 Wis 2d 497, 630 NW2d 182, 196-97 (2001) (stating that "it is within the circuit court's discretion to determine whether benefits received from a source collateral to employment should offset an award of back pay or front pay").

50 See Lussier, 50 F3d at 1105 (holding that "it is within the trial court's discretion to tailor a front pay award to take account of collateral benefits in a discrimination case").

51 Id at 1108.

52 See id, citing United States v O'Neil, 11 F3d 292, 296 (1st Cir 1993).

53 Id at 1108. 
purpose of Title VII. ${ }^{54}$ Senator Harrison Williams explained: "The provisions of this subsection [706(g)] are intended to give the courts wide discretion exercising their equitable powers to fashion the most complete relief possible." "ss

Courts have interpreted this to mean that trial courts have wide discretion in fashioning equitable remedies. ${ }^{56}$ However, this interpretation ignores the Supreme Court's declaration that "Congress' purpose in vesting a variety of 'discretionary' powers in the courts was not to limit appellate review of trial courts, or to invite inconsistency and caprice, but rather to make possible the 'fashion(ing) (of) the most complete relief possible."," If the goal is to create the most complete relief possible, it is simply a non sequitur to require that a trial court have discretion in every part of the remedy. Rather, the rule most faithful to congressional intent is the one that achieves the most complete relief possible. A universally applicable rule of no offset accomplishes that goal by encouraging a system where the benefits can be recouped by the agency.

\section{Lack of precedent.}

The Lussier court's second argument-that precedent dictates a rule of discretionary offset-also fails. The court stated that the "weight of authority unquestionably favors" granting courts discretion in considering collateral benefits in front pay awards and that the "virtually seamless array of precedents [are] worthy of [its] allegiance." $"$ "s9 However, the cited cases do not contain any truly persuasive reasoning that discretionary offset is required for front pay awards. They simply state that courts have the discretion to offset benefits without providing any real analysis to prove the point, while citing to other cases that also lack reasoning. ${ }^{\text {s. }}$ This circular logic does not make the solution to this question any clearer.

54 See, for example, Albemarle Paper Co v Moody, 422 US 405, 420-21 (1975).

55 Id at 421 (emphasis added), quoting 118 Cong Rec S 7168 (1972) (Sen Williams).

56 See, for example, Shore v Federal Express Corp, 42 F3d 373, 377-78 (6th Cir 1994) ("[A] district court has 'wide discretion' with regard to imposing equitable remedies so as 'to fashion the most complete relief possible' designed to 'make the victims of unlawful discrimination whole."), quoting Albemarle, 422 US at 421.

57 Albemarle, 422 US at 421 (quoting Sen Williams's remarks).

58 See Part IV.

59 Lussier, $50 \mathrm{F3d}$ at 1108 (citing cases). The collection of precedent is hardly seamless. See Hamlin v Charter Township of Flint, 165 F3d 426, 433-35 (6th Cir 1999) (holding that pension benefits may not be deducted from front pay awards under the ADA); Doyne $v$ Union Electric Co, 953 F2d 447, 451-52 (8th Cir 1992) (holding that pension benefits may not be deducted from front pay or back pay awards under the ADEA).

60 The first case cited by Lussier is Hukkanen $v$ International Union of Operating Engineers, 3 F3d 281, 286 (8th Cir 1993) ("The calculation of front pay, which is necessarily uncertain, is a matter of equitable relief within the district court's sound discretion."). Hukkenen provides 


\section{Implications of the "uncertain nature" of front pay.}

The Lussier court also based its support for a rule of discretionary offset on the "uncertain nature" of front pay. After noting that the precedent for discretionary offset is less clear for back pay, ${ }^{61}$ the court argued that "front pay presents an easier call." It reasoned that because of its "speculative nature" and "predictive aspect" front pay is "less mechanical" and "less certain" than back pay, therefore making it more dependent on the trial court's "exercise of its informed discretion." ${ }^{63}$

Although it is certainly true that front pay is less certain, the court neglected to consider the nature of the benefits to be awarded. Collateral benefits related to front pay are themselves "speculative" for similar reasons, because judges and agencies cannot predict the amount of the benefit that the employee will receive in the future.

no explanation for the proposition other than a citation to MacDissi $v$ Valmont Industries, Inc, $856 \mathrm{~F} 2 \mathrm{~d} \mathrm{1054,1060}$ (8th Cir 1988). In fact neither of these cases involved collateral benefits, and the only relevant issue in MacDissi was whether it was appropriate to award front pay at all. See id. The next case Lussier cited was Johnson v Chapel Hill Independent School District, 853 F2d 375, 382 (5th Cir 1988) (holding that a district court has discretion to deduct unemployment benefits from back and front pay under Title VII). Again, this case contained no reasoning for this proposition and relied only on a citation to Merriweather $v$ Hercules, Inc, 631 F2d 1161 (5th $\mathrm{Cir}$ 1980). Merriweather stated that offset avoids double payment and that the court had discretion to order this; however, it did not explain why this discretion exists. See id at 1168. Additionally, another circuit explicitly rejected Merriweather at an en banc hearing. See Brown v A.J. Gerrard Manufacturing Co, 715 F2d 1549, 1550 (11th Cir 1983) ("We now hold as a matter of law that unemployment compensation benefits received from a state fund, even if supported by a tax on employers, may not be deducted from a Title VII back pay award, and overrule Merriweather as precedent in this Circuit."). The third case cited by Lussier is Jackson v City of Cookeville, 31 F3d 1354, 1360 (6th Cir 1994) (affirming a trial court's use of discretion in offsetting a front pay award because the plaintiff had asked for the back pay award to be offset). As pointed out in Hamlin, the plaintiff in Jackson acted against his own interest in requesting an offset of his back pay award, so the case should be viewed as an anomaly and not as precedent. See Hamlin, 165 F3d at 434 ("Because the Jackson plaintiff acted against his own interests and contrary to the collateral source rule, Jackson should not be regarded as precedent ... [r]ather, the ultimate result of Jackson should be viewed as an unusual and inapplicable exception to the collateral source benefits rule."). The final case cited by Lussier is Graefenhain v Pabst Brewing Co, 870 F2d 1198, 1210 (7th Cir 1989) ("Whether to deduct pension benefits from a front pay award is a matter committed to the discretion of the trial court."). This is the only cited case that contains any relevant substance. It argues that courts "must examine the nature of the particular employer's pension plan to determine whether a deduction is appropriate ... [by] determin[ing] whether the employee has reaped a greater benefit by receiving his pension payments early rather than at a later date." Id. However, as that same circuit has noted, a system returning this benefit to the pension plan is preferable to granting an offset. See Hunter $v$ Allis-Chalmers Corp, Engine Division, 797 F2d 1417, 1429 (7th Cir 1986) (arguing that the proper analysis "is not that [the employer] should get a deduction ... but that [the employee] should have to repay [the benefits], since he neither paid for them nor was an intended donee").

61 See Lussier, $50 \mathrm{F3d}$ at 1108-09 (stating that by its "rough count, courts of appeals have divided four-to-three" in favor of discretionary offset for back pay).

62 Id at 1109.

63 Id. The court also noted that front pay is fully within the trial court's discretion while "back pay is a presumptive entitlement." Id at $1109 \mathrm{n} 7$. 
Thus, the belief that a judge's discretion will result in the most complete relief possible is faulty because it relies on the assumption that a judge can control for the unknown factors that influence the amount of collateral benefits.

\section{The nature of equity.}

Finally, the Lussier court argued for discretionary offset on the basis that "a black-or-white rule ... would simply not comport with the essential character and function of equitable discretion." ${ }^{, 55}$ It explained that the "storied heritage" of equity dictates that courts must be allowed to consider the particular facts of the case because it is impossible to make a law that does not fail under some circumstances. ${ }^{\text {.6 }}$

While granting courts flexibility is a reasonable objective, insisting that judicial discretion is required to achieve equity is nothing more than a mere categorization. The specific goals of the discrimination statutes should not be trumped by a general command of equity. The main goal of equity, and courts in general, is to reach the decision

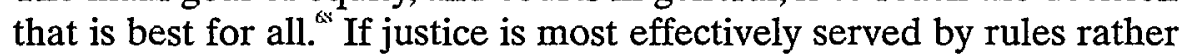
than discretion, then courts should welcome that. In fact, many decisions in the world of employment discrimination that are deemed "discretionary" are actually discretionary in title only. ${ }^{69}$ Courts should not allow this labeling to interfere with the goals of the employment discrimination statutes.

In affirming the trial court's decision to exercise its discretion and offset the collateral benefits, the Lussier court noted that as between the two primary purposes of the statutes-eradicating discrimination and making the victim whole ${ }^{70}$-the "goal of compensation ... is likely [] more important in regard to front pay ... [because] the basic function of a front pay award is to make victims of discrimination whole."

64 The fact that these benefits, by definition, have not been paid out at the time of adjudication makes it much easier for the agency to account for the benefits as they arise by simply not distributing them. See text accompanying notes 115-20.

$6550 \mathrm{~F} 3 \mathrm{~d}$ at 1110.

66 Id ("The imposition of a rigid rule ... would be incongruent with the historic and essential conception of equity.").

67 The purpose of equity itself is to avoid rigid results. See Dan B. Dobbs, 1 Law of Remedies: Damages-Equity-Restitution $\$ 2.1(3)$ at 63 (West $2 \mathrm{~d}$ ed 1993) ("Equity is said to be flexible rather than rigid, its interest justice rather than law.").

$6 s$ See John J. Kircher and Christine M. Wiseman, 2 Punitive Damages: Law and Practice $2 d$ $\$ 20: 4$ (West 2000) ("[T] he overall goal of equity [is] to achieve justice between the parties.").

69 See Dobbs, 2 Law of Remedies $\$ 6.10(6)$ at 235 (cited in note 1) (arguing that decisions such as whether to deny compensation or to order reinstatement are, in spite of their discretionary character, required and routinely awarded so that "[e]very single one of these claims to discretion must be taken with a grain of salt").

70 See text accompanying note 40 .

$7150 \mathrm{~F} 3 \mathrm{~d}$ at $1112 \mathrm{n} 10$. 
Although, it may be true that "[d]eterrence is a function of degree," this rationale does not consider the argument that allowing employers to avoid bearing the full costs of their actions will lead to more (and inefficient levels of) discrimination. ${ }^{73}$ While it is certainly important that front pay awards make victims whole, there is no justifiable reason to place one goal ahead of the other when both can be accomplished. ${ }^{74}$

\section{The No Offset Rule}

Courts holding that collateral benefits cannot as a matter of law be deducted from front pay awards have not based their rulings on any textual grounds. ${ }^{75}$ Generally, the courts advocating such a rule have considered the practical effects of the various potential rules.

First, courts have reasoned that a consistent rule is preferable to a grant of discretion. In Hamlin $v$ Charter Township of Flint, ${ }^{76}$ the Sixth Circuit determined that the issue of whether to deduct pension benefits from a front pay award was a "question of legal policy" and argued that such a "policy determination [ ] should not be left to the individual discretion of each district court.", Other courts have agreed that this matter should be covered by a definitive rule, arguing that a "consistent approach to this legal question seems preferable to a vir-

72 Id at 1112.

73 See, for example, Gaworski v ITT Commercial Finance Corp, 17 F3d 1104, 1113 (8th Cir 1994) (noting that offsetting back pay awards by collateral benefits "makes it less costly for the employer to wrongfully terminate a protected employee and thus dilutes the prophylactic purposes of a back pay award"). See also Minna J. Kotkin, Public Remedies for Private Wrongs: Rethinking the Title VII Back Pay Remedy, 41 Hastings L J 1301, 1306-07 (1990) (arguing that limits to discrimination awards, such as offsets for mitigation and reinstatement rules, provide too little incentive for victims to bring suits and too little incentive for employers to examine their practices).

74 See Franks v Bowman Transportation Co, 424 US 747, 787 (1976) (Powell concurring in part and dissenting in part) (noting in a Title VII case that remedies such as back pay "serve[] to work complete equity by penalizing the wrongdoer economically at the same time that [they] tend] to make whole the one who was wronged").

75 A statutory interpretation argument has been made claiming that back pay cannot be offset under Title VII. See Craig $v$ Y \& Y Snacks Inc, 721 F2d 77, 82 (3d Cir 1983) (stating that since Congress only provided for deductions from "interim earnings and amounts earned with reasonable diligence," no other deductions should be granted); Lee, Comment, 43 Emory L J at 350 (cited in note 23) (arguing that the principle of expressio unius does not allow the deduction of unemployment benefits from back pay because Title VII specifically lists interim earnings and amounts earnable with reasonable diligence as items that shall be deducted from back pay). However, because front pay is not addressed under any of the employment discrimination statutes this argument does not apply to this discussion. Additionally, this section of Title VII only deals with the mitigation of damages. It is questionable to assume that these terms are related to collateral benefits. See note 37 and accompanying text.

76165 F3d 426 (6th Cir 1999).

77 Id at 432. See also Jackson $v$ City of Cookeville, 31 F3d 1354, 1359 (6th Cir 1994) (stating that the "collateral source rule is a substantive rule of law").

78 Hamlin, 165 F3d at 433. 
tually unreviewable discretion which may produce arbitrary and inconsistent results." ${ }^{\text {,7 }}$ The Supreme Court noted that even though equity "eschews mechanical rules" and "depends on flexibility," when Congress invokes equity, "what is required is the principled application of standards consistent with [the] purposes [of the Act] and not 'equity (which) varies like the Chancellor's foot."

A second justification for a no offset rule is the belief that the victimized employee is more deserving of the excess. The Hamlin court reasoned that applying the collateral source rule against employers was desirable because it would "prevent[] the discriminatory employer from avoiding liability and experiencing a windfall, and also promote[] the deterrence functions of discrimination statutes." courts also advocate creating a rule that places the "loss" on the employer."

Finally, some courts have argued in favor of a no offset rule based on the objective of the collateral benefit itself. They point to the fact that the collateral benefits serve a completely independent purposesocial betterment-that is totally separate from any liability of the employer. The most persuasive argument for a rule of no offset is that the best way to deal with any unfairness between the parties is to have the agency recoup the benefit. ${ }^{84}$ As discussed in Part IV, courts should adopt a rule of no offset because it is the rule that best facilitates recoupment of benefits by agencies.

\section{PROBlems WITH THE DISCRETIONARY OFFSET RULE}

While several courts have advocated a rule of discretionary offset for collateral benefits in employment discrimination, too little consideration has been given to the effects of such a rule. This Part explains

79 Brown v A.J. Gerrard Manufacturing Co, 715 F2d 1549, 1551 (11th Cir 1983) (holding that unemployment compensation may not be deducted from back pay awards under Title VII). See also Dominguez v Tom James Co, 113 F3d 1188, 1189 (11th Cir 1997) (citing Gerrard in holding that Social Security benefits cannot be deducted from front pay or back pay in ADEA suits).

80 Albemarle Paper Co v Moody, 422 US 405, 417 (1975). See also Craig, 721 F2d at 85 (citing Albemarle and noting that a uniform rule will "avoid the conflicting results reached when such an issue is left to the discretion of district courts").

81 Hamlin, 165 F3d at 434.

82 See Maxfield v Sinclair International, 766 F2d 788, 795 (3d Cir 1985) (stating in a back pay case under the ADEA that "[a]s between the employer, whose action caused the discharge, and the employee... it is fitting that the burden be placed on the employer").

83 See, for example, Craig, 721 F2d at 84 (holding that allowing an offset of unemployment compensation from a back pay award would undercut this policy), citing EEOC $v$ Ford Motor Co, 645 F2d 183,196 (4th Cir 1981).

84 See Craig, 721 F2d at 85 (stating that the recoupment of [the] benefits by the state is the better way of dealing with any possible unfairness"); Kauffman v Sidereal Corp, 695 F2d 343, 347 (9th Cir 1982) (stating that the "logical solution" to the problem is recoupment by the state agency). 
the functional problems (both actual and potential) that can arise from a rule of discretionary offset. It also suggests that a simple, uniform rule, applicable to all circumstances, is both possible and desirable.

\section{A. Problems in the Application of Discretionary Offset}

When choosing a rule, it is important to look closely at the consequences of each rule's application. The consequences of the discretionary offset rule illustrate why courts should adopt a universal rule of no offset.

1. No guidance for how courts should exercise their discretion.

Circuit courts advocating a rule of discretionary offset have created a system of uncertainty. No circuit has developed a clear, functional standard that would instruct trial courts on when they should exercise their discretion and offset the award by the amount of the collateral benefits.

The few proposed standards have provided little guidance for trial courts. For example, one judge suggested that courts should "deduct unemployment benefits from a back pay award, except in rare circumstances which [the judge could not] readily envision." "This judge's suggestion is an example of how some courts may abuse their discretionary power by relying on overly broad rationales, and such a rule certainly provides no standards for other courts to use. One article has suggested, "The decision of whether to permit the offset of collateral benefits ultimately hinges on whether the court is more concerned with adequately compensating existing plaintiffs or with deterring future wrongs." ${ }^{\text {,7 }}$

Another judge recommended that courts should consider the blameworthiness of the employer in deciding what to do with the excess. ${ }^{88}$ Judicial manipulation of discrimination awards is not the proper

85 See Brown v A.J. Gerrard Manufacturing Co, 715 F2d 1549, 1551 (11th Cir 1983) (noting the lack of standards in deciding whether to deduct unemployment benefits from back pay awards under Title VII). See also Lee, Comment, 43 Emory L J at 336-38 (cited in note 23) (noting that courts "have not put forth meaningful standards to guide the discretion").

86 Craig $v Y \& Y$ Snacks, Inc, 721 F2d 77, 87 (3d Cir 1983) (Seitz dissenting in part) (stating that he agreed that it is desirable to fashion a rule to minimize conflict among the courts about whether to deduct the benefits and claiming that his rule would somehow "provide that uniformity"). See also Dobbs, 2 Law of Remedies $\$ 6.10(6)$ at 236 (cited in note 1) (describing discretion in remedies as a misnomer that stands for rules "the exceptions to which cannot yet be specified in detail [which] encourages decisions that are not explained and perhaps ... cannot be explained with rationality").

87 John H. Mason and Christopher L. Ekman, Defending Against Damages Claims in Discrimination Cases, 13 Labor Law 471, 490 (1998).

88 See Hamlin, 165 F3d at 441 (Nelson concurring in judgment) (hypothesizing that an em- 
place to address this issue of the degree of blameworthiness. If Congress wants more blameworthy employers to face additional punishment it can do so through express provisions like punitive damages.

The consequence of this lack of guidance is that court decisions will be inconsistent. ${ }^{90}$ Therefore, outside agencies will not be able to predict what courts will do, meaning they will not know how to act. This may result in a waste of agency time because the agency will continue to pay out benefits it may later try to recover."

\section{Rough justice problem.}

Another problem with permitting courts to exercise discretion in deducting collateral benefits from discrimination awards is that they may decline to deduct the benefits as a rough way to compensate the employee for other losses that he may face, such as the costs of searching for new employment. ${ }^{\text {s2 }}$ Several courts have cited this as a reason not to exercise their discretion to deduct collateral benefits. ${ }^{93}$ This idea of "rough justice" can create a problem by disguising what the damage award really represents.

This reasoning creates several problems. First, if a plaintiff is not entitled to recover such expenses under the statute, courts should not fashion extra compensation to provide it." Second, if the plaintiff is

ployer who refuses to hire an employee based on race is more blameworthy than an employer who does so because the employee does not have the ability to perform the functions it believes are essential to the job). Judge Nelson argued that trial courts should be able to consider this degree of fault in the offset decision, but concurred with the court's ruling that the award cannot be offset because the decision to do so was an abuse of discretion. See id.

89 See 42 USC \$ 1981a(a)1 (providing for punitive damages under Title VII if the discrimination is intentional).

90 See Part III.B.

91 See Part IV.A.

92 This was first suggested by the Supreme Court in Gullett, 340 US at 364 ("[N]o consideration has been given or should be given to collateral losses in framing an order to reimburse employees for their lost earnings, manifestly no consideration need be given to collateral benefits which employees may have received.").

93 See, for example, Kauffiman v Sidereal Corp, 695 F2d 343, 346-47 (9th Cir 1982) (holding that unemployment benefits should not be offset against a back pay award under Title VII while citing the "rough justice" language from Gullett); EEOC v Sandia Corp, 639 F2d 600, 624-26 (10th Cir 1980) (citing Gullett in affirming decision not to offset unemployment benefits from back pay award in ADEA suit). See also Hunter $v$ Allis-Chalmers Corp, 797 F2d 1417, 1429 (7th Cir 1986) (arguing in a Title VII case that allowing the plaintiff to "keep the remaining [excess] unemployment benefits is a crude but not unreasonable recompense" because a mistake by the state's unemployment office caused erroneous overpayment to be deducted from future payments). Hunter is somewhat distinguishable from the other cases because Judge Posner recognizes that the excess benefits are best returned to the payors or the distributing office. See id. However, since the ultimate payors of the benefits are a "diffuse and unascertainable group" and "not asking for the return of the benefits," Judge Posner allows the plaintiff to retain the excess in compensation for the mistake of the office. Id.

94 Congress has been careful to limit the types of remedies available under the employment discrimination statutes. See, for example, 42 USC $\$ 1981$ (a)(1) (providing punitive dam- 
entitled to recover the expenses, it is important for the court to clearly define what damages it is actually awarding."

Courts applying this theory of rough justice create special problems when agencies look to damage awards in trying to determine what has been done with an excess benefit. State recoupment statutes already in place for back pay instruct the agency to determine where the excess benefit was placed and institute actions allowing for the return of that amount. ${ }^{96}$ A court decision that attempts to distribute benefits under a theory of rough justice will make it impossible for the agency to know from which party it should seek to recoup its money.

\section{B. Lack of a Uniform Background Rule}

Another major problem with the discretionary offset rule is that the rules differ not only by jurisdiction, but also by statute and by benefit. ${ }^{\text {" The }}$ There no rational reason to have these differences when all of the employment discrimination statutes are part of a "wide[] statutory scheme to protect employees in the workplace nationwide." Similarly, there is no reason to treat the type of collateral benefit differently; varying rules create confusion for litigants, courts, and agencies. A simple background rule applicable to all situations would be the best way to implement the statutory scheme. A default rule allows

ages under Title VII only if the discrimination is intentional).

95 The Seventh Circuit cautioned lower courts to "be vigilant to ensure that their damage inquiries are appropriately cabined to protect against confusion and potential overcompensation of plaintiffs." Williams v Pharmacia Inc, 137 F3d 944, 954 (7th Cir 1998) (advising lower courts to separate front pay from lost future earnings because "the two types of damages compensate for different injuries and require the court to make different kinds of calculations and factual findings").

96 See, for example, Iowa Code Ann § 96.3-8 (West 1996) (requiring recovery of excess unemployment benefits, and requiring the agency to "allow the employer to deduct the amount of the [excess] benefits from the back pay and remit a sum equal to that amount to the unemployment compensation fund and the balance to the individual, or to recover the amount of the [excess] benefits either by having a sum equal to that amount deducted from any future benefits payable to the individual or by having the individual pay to the department a sum equal to that amount").

97 Within one year, the Ninth Circuit held that courts could not deduct unemployment benefits from a Title VII back pay award, but could exercise discretion in deducting unemployment benefits from an ADEA back pay award. Compare Kauffman $v$ Sidereal Corp, 695 F2d 343, 347 (9th $\mathrm{Cir}$ 1982) ("We ... hold that unemployment benefits received by a successful plaintiff in an employment discrimination action are not offsets against a [Title VII] backpay award."), with Naton v Bank of California, 649 F2d 691, 700 (9th Cir 1981) (holding that the district court had discretion to deduct unemployment benefits from an ADEA back pay award).

98 McKennon v Nashville Banner Publishing Co, 513 US 352, 357 (1995) (discussing the ADEA and citing Title VII, the ADA, and the NLRA).

99 See Maxfield v Sinclair International, 766 F2d 788, 795 (3d Cir 1985) ("There are no significant discernible differences between Social Security benefits, unemployment benefits and pension benefits .... [a]ll would ordinarily be received by an employee ... only after $\mathrm{s} / \mathrm{he}$ has been discharged or involuntarily retired."). 
easy and predictable administration of justice-judges will know how to rule, ${ }^{160}$ employers and employees will know what to expect. Furthermore, agencies will know up front how to act to recoup the benefits rather than having to wait for a judicial decision and then react to undo what they have already done. The employment discrimination statutes do not mandate a particular type of rule, ${ }^{101}$ so choosing a uniform default rule will not contravene any statutory requirement.

\section{COURTS SHOULD ADOPT A UNIVERSAL RULE OF NO OFFSET FOR FRONT PAY AWARDS}

The fundamental dilemma raised by the possible offset rules is that courts must still deal with an excess of funds regardless of which rule they adopt. Allowing the employee to receive both a full front pay award and the collateral benefit creates a double recovery and provides him with an undeserved windfall. Alternatively, allowing the employer to deduct the benefit from the front pay would underdeter it from discriminating, even though the employee will be correctly compensated. The simple answer to this problem is to get rid of the excess benefit-meaning that the agency should stop paying out the benefit. Some courts have suggested that the ideal solution in back pay situations is to have the excess benefit recouped by the agency that distributes it. ${ }^{103}$ Additionally, many states already have statutes set up for similar situations arising under back pay awards. ${ }^{104}$

Courts should choose the offset rule that best facilitates recoupment statutes for state-run agencies and recoupment policies for private agencies. Clarity and efficiency dictate that this is a rule of no offset for awards of front pay. Under this rule, employees should receive their front pay award from an employer, regardless of collateral benefits. The agency can then be notified of the decision and take the proper steps to stop or reduce the level of benefits, so that the employee is not overcompensated. Courts should explicitly state that this is the proper system and encourage agencies to develop the necessary procedures to implement it.

100 Judges will still have to be cognizant of any changes in employment discrimination law. See Part IV.C.

101 See Part I.C.2.

102 This Comment is only arguing for a default rule. Any new or modified statute that dictates a specific rule would clearly trump such a background rule. It may be necessary to apply different background rules for front and back pay, but this distinction is easy for courts to make and is easily recognizable for agencies.

103 See note 10.

104 See note 12. 


\section{A. Clear Rule of No Offset Facilitates Agency Recoupment}

Several courts have argued that a uniform rule is preferable to leaving this decision to the discretion of the trial court. ${ }^{105}$ A further factor in favor of a uniform rule is that its clarity ensures that the excess benefit can be returned to the distributing agency. A clear and specific rule that no award of front pay will be offset by collateral benefits means that all of the parties know how to act so that the agency providing the benefit can easily recoup it.

1. Signaling to third parties.

The best way to ensure that the party providing the benefit retains any excess is to create a clear and dependable rule, so that the agency knows exactly what the court will do. This rule should be the same regardless of the benefit considered or the discrimination statute that governs the case. ${ }^{106} \mathrm{~A}$ rule varying by discrimination statute would require the agency to create a variety of systems to retrieve the benefit for each independent statute. ${ }^{107}$ A rule that varies by type of benefit may make it unclear to the third party agency what action it should take. ${ }^{108}$ Furthermore, in both instances there are no differences that should warrant differential treatment as a matter of law. ${ }^{100}$

In creating a rule of no offset, the court should announce to the agencies that distribute funds that it is enforcing the rule in order to facilitate the recoupment of the benefits. If the court does not signal its desire for the agency to recoup the benefit, it can only distribute the money among the present parties. To implement a plan effectively-placing all parties in the correct position-the agency must know that the proper course of action for it to take is to recoup any prior overpayment and stop any future payments that would overcompensate the employee. The court can use such a case as a platform

105 See Hamlin, 165 F3d at 433 (stating that the decision to offset benefits should not fall within the district court's discretion); Dominguez $v$ Tom James Co, 113 F3d 1188, 1191 (11th Cir 1997) (favoring a uniform rule for back pay under the ADEA); Brown v A.J. Gerrard Manufacturing Co, 715 F2d 1549, 1551 (11th Cir 1983) (favoring a uniform rule for back pay under Title VII).

106 See Part III.B.

107 For example, a rule that unemployment benefits may be deducted under Title VII but not under the ADEA would mean that the benefit coordinator would have to establish systems for retrieving the benefit from the employee under Title VII, the employer under Title VII, and the employee under the ADEA. A rule of no deduction would simply require one system to retrieve the benefit from the employee in every case.

108 For example, a rule that pension benefits may be deducted but disability benefits cannot may cause confusion in a privately operated retirement plan that factors disabilities into its decisions.

109 See note 99 and accompanying text. 
to instruct the agencies on how to act in the particular case at hand as well as in the future."

2. Solving the "rough justice" problem.

Discretionary offset of collateral benefits gives courts an opportunity to compensate employees for other damages under the guise of not deducting collateral benefits. ${ }^{\text {"1 }}$ Mixing damages may actually lead to undercompensating the employee. For example, a court may grant the employee an award of front pay based on his employer's violation of the ADEA. Applying a rule of discretionary offset, the court may decide not to deduct the collateral benefit because of other expenses that the victim suffered (such as costs in seeking other employment). The agency may then-either by individually reviewing the case or by acting pursuant to a statute mandating recoupment-seek to recover that amount from the victim, leaving him undercompensated.

Conversely, a rule stating that the court cannot deduct these benefits will ensure the proper distribution of liability and compensation. Under a rule of no offset, the court awards the employee front pay for future lost wages and, if the statute allows, awards separate damages for the costs of seeking out new employment. ${ }^{112}$ Then, when the agency seeks to recoup the excess benefits, the employee will remain in the position that the court intended. If nothing else, this rule will reduce any transaction costs and confusion in communication between the court and the agency. This is because the agency will not be forced to inquire whether the benefits were actually deducted from the award.

\section{B. Rule of No Offset Increases Efficiency}

Another benefit of the proposed solution is that it will increase efficiency in the judicial system. Most importantly, it will ensure that the excess benefit is placed in the proper hands (those of the agency) rather than an arguably undeserving party (either the employee or

110 This will have the benefit of informing the agencies to create a procedure to recover excess benefits in future cases, to intervene in the current case, and to institute an action to recover the excess benefits if such a mechanism is not in currently place. See Jirus $v$ City of Berwyn, 712 F Supp 672, 674 (N D Ill 1989) (stating that the state-run pension fund that intervened to claim the excess benefit "certainly would have prevailed in recovering the[ benefits" in a subsequent action had it not intervened in the current case).

111 See Part III.A.2.

112 The ADEA provides courts with the power to "grant such legal or equitable relief as may be appropriate to effectuate the purposes" of the Act. 29 USC $\$ 626(\mathrm{~b})$. This example is not applicable to Title VII, which does not provide courts with the power to grant legal remedies. However, a similar hypothetical could demonstrate the same principle using Title VII's provision of punitive damages on top of compensatory damages for intentional discrimination. See 42 USC § 1981a(a)(1). 
employer). On top of creating the correct distributional scheme, this solution will also cut down on judicial costs.

\section{Administrative efficiency.}

A rule of no offset for collateral benefits in front pay awards has an efficiency benefit that does not exist with a similar rule for back pay. As courts have stressed, the world of front pay is uniquely speculative. ${ }^{113}$ Courts have argued that this predictive nature calls for more discretion in considering collateral benefits. ${ }^{114}$ However, when viewed within the context of a system aimed at agency recoupment, this speculative nature is actually an argument against discretion, and for a rule of no offset.

For awards of front pay, the relevant collateral benefits have not yet been awarded to the employee. ${ }^{15}$ Under a rule of discretionary offset, any time that the benefits are actually offset the agency would have to recoup them by initiating an action to force the employer to make monthly payments over the course of the front pay or by forcing it to make a lump sum payment of the benefits to be paid out. ${ }^{116}$ The rule barring such deductions creates a much simpler system. Under the no offset regime, the agency will simply reduce the amount of the benefits it pays to the level it would pay out if the plaintiff were to remain employed for the duration of the front pay award period. ${ }^{117}$ This efficiency argument works in the opposite direction for back pay awards, because, by definition, those benefits have already been paid to the employee."

113 See Lussier, 50 F3d at 1109-10 (comparing front pay to back pay).

114 See text accompanying notes $61-63$.

115 This is not the case when there is a lump sum payment. In such a case the agency will be forced to institute an action to recover the funds from whichever party receives the windfall. So a rule of no offset would be no less efficient than a discretionary rule, and would still have the benefit of signaling to the agency to whom to go for recovery.

116 This lump sum payment comes with the additional cost of having to calculate the present value of the benefits. This is procedurally inefficient because the cost of the calculation is unnecessarily imposed on the court or the agency. More importantly, it may be distributionally inefficient because the court and the agency will not have the information needed to make this calculation. See Dobbs, 2 Law of Remedies $\$ 8.5(3)$ at 470 (cited in note 1) (stating that present valuation is a function of three variables: the amount due in the future, the date on which it is due, and the discount rate). By definition these "front pay" benefits have not yet been determined, so the parties will have to estimate their level, as well as when they will be distributed.

117 If the agency would not have paid the employee any benefits without the illegal discharge, then the agency would simply stop sending any payments.

118 For example, in a state with a rule of no offset, the state would pay an employee a full back pay award and then have to recoup the amount of the benefit in a separate action. Such a rule would require two steps to do something that could be accomplished in one. This means that for agency recoupment of state-funded back pay awards, efficiency dictates that collateral benefits should be deducted as a matter of law (a rule of offset). See Dillon $v$ Coles, 746 F2d 998, 1007 (3d Cir 1984) (holding that efficiency concerns justified disregarding the precedent of not allowing offset in back pay awards because the suit was against the state and a statute called for re- 
The employer also receives a benefit from a no offset rule for front pay. Employer contributions can be tied to the amount of benefits paid to employees, so that a system where benefits are offset and then recouped from employers means that they are actually being over-penalized. ${ }^{119}$ This problem is alleviated in front pay cases by a rule of no offset. The agency will stop payment on future benefits during the front pay period so that without any payments the employer will not face increased contributions.

Another form of administrative efficiency supporting the rule of no offset is that the agency awarding the benefits will be in a better position to know what the value of the benefits are. For example, in Lussier, the trial court had difficulty determining how much to offset the front pay award because it could not calculate the increase in benefits resulting from the termination. ${ }^{120}$ Ultimately, the court postponed the final judgment until the benefits could be calculated by the agency.1 The agency did not respond within the court's thirty-day waiting period, or the additional ten-day extension. ${ }^{12}$ Frustrated by this communication problem, the court calculated the deduction using the benefits that the plaintiff was receiving on an interim basis. ${ }^{123}$ The agency later calculated the amount of the benefits, arriving at an amount substantially different than the number the court had used, ${ }^{12}$ but the judge declined to alter the judgment. ${ }^{125}$ Not only did this ruling result in an incorrect allocation of liability, but it also led to great aggravation and delay in the judicial system.

A rule of no offset would have been much more efficient. First, there would be no rush for the agency to determine the amount of the benefits. Whenever the correct increase was calculated, it could have been deducted from the payments. More importantly, there should be

coupment of the benefits, consequently it would be wasteful of public funds to require the state to institute a suit to recover the funds from the employee). This argument only works for cases with the same entity-for example, the state-representing the employer and the agency. Without this unity of interests, the recoupment cannot be folded into a one-step process.

119 See Craig v Y \& Y Snacks, 721 F2d 77, 86-87 (3d Cir 1983) (Seitz dissenting in part) (noting that state statutes providing for increased employer contributions based on benefits paid to employees in the previous year along with a state recoupment provision mean that a victim is not made more than whole, while the employer must pay out more than a make-whole sum in the aggregate).

120 See Lussier, 50 F3d at 1106.

121 Id.

122 Id at $1106-07$.

123 See id (basing the offset on the $\$ 390$ per month the plaintiff was receiving pending the determination of his final entitlement).

124 See id at 1107 (calculating the benefit to be $\$ 1,111$ per month).

125 See id (stating that even though this would result in a windfall to the plaintiff, changing the relief would make a "mockery of [ ] judicial deadlines").

126 The First Circuit did not allow this incorrect remedy to stand; it remanded the case to recalculate the compensation. See id at 1115. 
no reason for the agency to have to calculate the increase at all. By applying the rule of no offset in an agency recoupment regime, the agency would simply continue to provide the same level of benefits it had before the termination throughout the period of the front pay award. ${ }^{127}$ The proposed solution is much more efficient for both the court and the agency, and the employee benefits from having a simpler resolution to the dispute. ${ }^{128}$

\section{Agency expertise.}

Another advantage of not allowing courts to deduct collateral benefits from front pay is that it allows the agency, which likely has more expertise in the area, to decide whether the benefits are actually collateral, rather than earned by the plaintiff. ${ }^{129}$ If the agency decides that the employee earned the benefits because of previous contributions or forgone compensation it will continue to provide the benefit. Alternatively, if the agency determines that this payment is redundant, it will recoup the benefit. ${ }^{130}$ In a recoupment system, the employer will be forced to bear the full cost of its discrimination regardless of the agency's choice, so it should be indifferent. This rule saves the court's resources (as well as the litigation costs to the parties) and is more likely to elicit the "right" decision, simply because the agency is more familiar with the system and has greater access to the information.

A rule of no offset for front pay awards also means that courts are not forced to guess whether the discriminatory discharge will make the employee eligible for collateral benefits at an undisclosed time in the future. ${ }^{131}$ If the termination triggers additional benefits at some future time, the agency is able to withhold any payments until

127 The calculation of these benefits would not have to be made until after the front pay award was scheduled to stop.

128 The only party under these facts who would not be happy would be the employer who would no longer receive the windfall, which is not deserved. However, the employer actually would benefit in avoiding the lengthy litigation costs that Lussier no doubt entailed.

129. Several courts have decided that benefits should not be deducted from an award because the plaintiff "earned" them either as part of the regular compensation or by forgoing other benefits. See, for example, EEOC v O'Grady, 857 F2d 383, 391 (7th Cir 1988) (declining to deduct pension benefits from a back pay award under the ADEA because "the pension benefits [] were part of the claimants' compensation"); Salveson y Douglas County, 245 Wis 2d 497, 630 NW2d 182, 197-98 (2001) (declining to deduct disability benefits from back pay and front pay awards under Title VII because the plaintiff "paid for those benefits by foregoing pay increases and other benefits").

130 It would be best for the agency to determine this fact before it provides any benefits, and to notify the eligible employees so that no litigation between the agency and employee is required after the fact.

131 See Gotthardt v National Railroad Passenger Corp, 191 F3d 1148, 1158 (9th Cir 1999) (affirming the trial court's use of discretion not to deduct potential disability benefits from a front pay award in Title VII case because the plaintiff could only speculate as to whether the benefits might become available). 
the front pay period expires. This also avoids the delay and costs of forcing a court to revisit the issue.

\section{Role of Courts Under a No Offset Rule}

It should be noted that there is still a role for courts under the solution proposed by this Comment. For instance, because the proposed solution is only a background rule, courts will have to monitor any legislative action that would mandate a different rule. Based on the recent Supreme Court rulings regarding the ADEA and ADA, it is possible that the legislation will be revisited. . $^{132}$

Another issue that courts will have to consider is whether the benefits are actually provided by the employer. If the employer is the source of the benefit, it is not actually collateral, so the proposed solution would not apply. Because the collateral source rule is not implicated, the court will offset the front pay award so that the employer is not forced to pay twice. ${ }^{133}$

\section{CONCLUSION}

This Comment considered the question of what to do when employment discrimination results in a front pay award while also triggering collateral benefits. This situation creates an excess of resources to be distributed. There is no definitive answer from Congress in the discrimination statutes. The Supreme Court has not clearly addressed the issue, and the opinions of the circuit courts vary.

The ideal solution to this problem is to remove the excess benefit from the dispute, so that it does not have to be distributed to either side. This requires the agency controlling the benefit to step in and stop its payments. Since all of the discrimination statutes are interrelated, this is most easily accomplished by the creation of a uniform background rule for handling collateral benefits under all circumstances of front pay.

132 See notes 25-26 (citing Supreme Court cases holding that the ADA and ADEA are unconstitutional when applied against states by individuals). Courts would need to be aware of new federal legislation, or alternatively suits brought under state discrimination laws, which may dictate how to handle collateral benefits.

133 See, for example, Giles $v$ General Electric Co, 245 F3d 474, 495 (5th Cir 2001) (holding that because the employer is obligated to pay the plaintiff's disability benefits they are not collateral, and therefore should be offset from the award of front pay order to keep the employer from paying twice for the same injury); Davis v Odeco, Inc, 18 F3d 1237, 1244 n 21 (5th Cir 1994) ("Properly interpreted, ... the collateral source rule [ ] prevents tortfeasors from paying twice for the same injury-a result that would achieve both overdeterrence and overcompensation."). But see Lee, Comment, 43 Emory L J at $341-46$ (cited in note 23) (arguing that unemployment compensation is a collateral source despite contributions by the employer because the employer must make these contributions whether or not they take discriminatory actions). 
A rule of no offset will help create systems for recouping these benefits and ensure the proper distribution of resources. It allows the employee to be fully compensated, provides the proper level of deterrence to the employer, and enables the agency to recoup the benefit easily. Therefore, courts should apply a background rule of no offset for all front pay awards. To encourage this system, legislatures-both state and federal-should enact employment laws that mandate agency recoupment of excess collateral benefits. 